\title{
COMPREHENSIVE STUDY OF MANAGEMENT OF DIAPHYSEAL FRACTURES OF LONG BONES IN CHILDREN BY TITANIUM ELASTIC NAILING SYSTEM
}

\author{
Mirza Shahid Baig1, Narasimharao Thutari², K. Kodandapani3 ${ }^{3}$,Kali Varaprasad Vadlamani4, Mahesh Tilak ${ }^{5}$ \\ ${ }^{1}$ Assistant Professor, Department of Orthopaedics, Government Medical College, Mahbubnagar, Telangana, India. \\ ${ }^{2}$ Associate Professor, Department of Orthopaedics, Government Medical College, Mahbubnagar, Telangana, India. \\ ${ }^{3}$ Former Professor and HOD, Department of Orthopaedics, Osmania Medical College, Hyderabad, Telangana, India. \\ 4 Professor, Department of Orthopaedics, Mediciti Medical College, Hyderabad, Telangana, India. \\ ${ }_{5}^{5}$ Senior Resident, Department of Orthopaedics, Kurnool Medical College, Kurnool, Andhra Pradesh, India.
}

\section{ABSTRACT}

\section{BACKGROUND}

Paediatric fractures are usually treated conservatively with POP casts, as intramedullary nailing is contraindicated in growing bones and plating is associated with wound complications. These fractures heal satisfactorily with conservative treatment but may be associated with malunion and plaster complications sometimes. Titanium Elastic Nailing System (TENS) can be used in the internal fixation of paediatric fractures with satisfactory results and minimal complications. We wanted to study the functional outcome following the use of Titanium Elastic Nailing for the treatment of diaphyseal fractures of long bones in children.

\section{METHODS}

30 patients were treated with Titanium Elastic Nail System (TENS) for diaphyseal fractures of long bones who were admitted in Osmania General Hospital, Hyderabad during the study period- from October-2014 to October-2016. Patients were assessed clinically, radiologically and the complications were noted.

\section{RESULTS}

We studied 17 (56.7\%) femoral, 7 (23.3\%) tibial fractures, 1 (3.3\%) humeral and 5 (16.6\%) forearm bone fractures. Average age of the patients is 10.93. In our study, the final outcome was excellent in $22(73.33 \%)$ cases, satisfactory in $8(26.67 \%)$ cases and there are no poor outcome cases.

\section{CONCLUSIONS}

We conclude that titanium elastic nailing system (TENS) technique is an ideal method for treatment of paediatric diaphyseal fractures of long bones.

HOW TO CITE THIS ARTICLE: Baig MS, Thutari N, Kodandapani K, et al. Comprehensive study of management of diaphyseal fractures of long bones in children by titanium elastic nailing system. J. Evolution Med. Dent. Sci. 2019;8(13):969-973, DOI: $10.14260 /$ jemds/2019/217

\section{BACKGROUND}

In the last two decades there was an increased interest in the operative treatment of paediatric fractures, although debate persisted over its indications. There is little disagreement concerning the treatment of long bone fractures in children less than 5 years (POP cast) and adolescents older than 16 years (locked intramedullary nailing). ${ }^{1}$ Controversy persists regarding the age between 5 to 16 years.

Orthopaedic surgeons will continue to be challenged to treat this age group with less morbidity at a lower cost, as no clear guidelines have been available until now despite efforts done initially by French surgeons, later on by European surgeons and recently by the Pediatric Orthopedic Society of North America (POSNA). ${ }^{2}$ Titanium elastic nail (TEN) fixation was originally meant as an ideal treatment method for femoral fractures, but was gradually applied to other long bone fractures in children, as it represents a compromise

'Financial or Other Competing Interest': None.

Submission 04-02-2019, Peer Review 16-03-2019,

Acceptance 23-03-2019, Published 01-04-2019.

Corresponding Author:

Dr. Narasimharao Thutari,

H. No. 7-5-106, Vandana Enclave,

Block-C, Flat No. 101, Venkateswara Colony,

Mahabubnagar-509001, Telangana, India.

E-mail: narasimharao.thutari@gmail.com

DOI: $10.14260 /$ jemds $/ 2019 / 217$

(c) $(7)$ between conservative and surgical therapeutic approaches with satisfactory results and minimal complications. ${ }^{2}$

\section{Aims and Objectives}

1. To study the functional outcome following the use of Titanium Elastic Nailing for the treatment of diaphyseal fractures of long bones in children in the age group between 5 to 16 years.

2. To study the safety of Titanium Elastic Nailing in the treatment of diaphyseal fractures of long bones in children in the age group between 5 to 16 years.

3. To evaluate the complications of Titanium Elastic Nailing in the treatment of diaphyseal fractures of long bones in children in the age group between 5 to 16 years.

\section{METHODS}

A case series of all children and adolescent patients between 5-16 years of age with closed, diaphyseal fractures of long bones admitted at Osmania General Hospital, Hyderabad during the study period from October-2014 to October-2016 were the subjects for the study. Patients with head injury were not included in the study. All the patients with Metaphyseal fractures, Compound fractures and Pathological fractures were excluded from the study. Each child was followed up to 1 year to 1 year 6 months after the surgery. 


\section{Procedure for TENS Nailing of Diaphyseal Fracture}

A systemic antibiotic, usually a 3rd generation cephalosporin was administered 1 hour before surgery. General/ Spinal anaesthesia is administered, and patient is placed in supine on a radiolucent table. The operative extremity is then prepared and draped. Under fluoroscopy, the fracture site and entry points are marked. The starting point for nail insertion is a point on metaphysis $2.0 \mathrm{~cm}$ away from the physis (Distal femur, proximal tibia, proximal/distal humerus, proximal ulna and distal radius). A longitudinal 2 $\mathrm{cm}$ incision is made on both the lateral and medial side of the metaphysis at the desired bony entry point. Using a haemostat, the soft tissues are bluntly dissected down to bone. Based on preoperative measurements, an appropriately sized implant is selected so that the nail diameter is $40 \%$ of the diameter of the narrowest portion of the medullary canal (it should be $60 \%$ if a single nail is used. A drill roughly 0.5 $\mathrm{cm}$ larger than the selected nail is then used to open the cortex at the nail entry site; angling the drill distally down the shaft facilitates nail entry. Both nails are then inserted through the entry holes and advanced to the level of the fracture site.

Under fluoroscopic guidance, the fracture is reduced in both the coronal and sagittal planes, and the first nail is advanced past the fracture site. If proper intramedullary position of the nail after crossing the fracture site is confirmed on anteroposterior and lateral views, then the second nail is tapped across the fracture site. Both nails are advanced until the tips lie just short of the physis at opposite end of the bone. Fluoroscopy is again used to confirm proper fracture reduction as well as nail position.

To minimize soft tissue irritation, the nails are backed out a few centimeters and cut along proximal tibial metaphysis. A tamp is used to re-advance the implants until $<1 \mathrm{~cm}$ of nail lies outside of bone. Care is taken not to bend the nails away from the bone to facilitate cutting, as we have found that this increases nail prominence and subsequent skin irritation. The two incisions for nail entry are closed in a layered fashion, and the wounds are well padded with gauze.

\section{After Surgery \\ Postoperatively, patients were immobilized in a slab support. Patients were started on static quadriceps exercises in case of lower limb fractures and active movements of fingers in case of upper limb fractures as soon as the pain subsided. POP cast was applied at the time of suture removal. POP cast was removed, and the range of motion exercise were started after 6 weeks. Partial weight bearing was started after visible callus was seen. With radiological evidence of union, full weight bearing was started after 6-8 wks. In patients with humerus fracture, fracture was either splinted or placed into a soft dressing and given a sling for comfort for 10-14 days. In case of forearm bone fractures, we immobilized the patient for 3 wks. in a posterior slab followed by allowing ROM exercises for elbow and wrist, sling for another 3 more wks.}

\section{Nail Removal}

Usually nails are removed from 6 to 9 months after the surgery, depending on radiological union.

\section{Follow Up}

Assessment was done at 6,12 and 24 weeks and at $1 \mathrm{yr}$. At each follow up patients were assessed clinically, radiologically and the complications were noted.

\section{Clinical Assessment}

1. Pain.

2. Range of movements.

3. Measurement of limb length - noted for shortening/ lengthening.

4. Time of weight bearing.

\section{Radiological Assessment}

- X-ray of the part (Thigh/leg/arm/forearm) full length with one joint above and one joint below - AP and LATERAL views

- Alignment: sagittal/coronal angulation (in degrees $-<10$ or $>10$ ) rotational malalignment (in degrees $-<10$ or $>10$ )

- Circumferential callus formation - good/adequate/poor.

- Visibility of fracture line - seen clearly/ masked/ not seen.

\section{Complications ${ }^{4}$}

1. Pain at the site of nail insertion,

2. Angulation (Sagittal, coronal and rotational malalignment) at final follow-up (24 weeks),

3. Limb length discrepancy (Shortening/lengthening) at final follow-up (24 weeks),

4. Inflammatory reaction to nails,

5. Superficial infection at site of nail insertion,

6. Delayed union,

7. Deep infection,

8. Loss of reduction requiring new reduction or surgery,

9. Delayed or non-union leading to revision.

The final outcome based on the above observations is done as per Flynn's criteria. Flynn's criteria.2,3,4

\section{RESULTS}

In the present study $6(20 \%)$ of the patients were $5-8$ years, $14(46.7 \%)$ were 9 to 12 years and $10(33.3 \%)$ were 13 to 16 years age group with the average age being 10.93 years. There were $8(26.7 \%)$ girls and $22(73.3 \%)$ boys in the present study.

In the present study RTA was the most common mode of injury accounting for $20(66.7 \%)$ cases, self-fall accounted for $8(26.7 \%)$ cases and fall from height accounted for $2(6.6 \%)$ of the cases.

We studied 17 (56.7\%) femoral, 7 (23.3\%) tibial fractures, $1(3.3 \%)$ humeral and 5 (16.6\%) forearm bone fractures. In our study, transverse fractures accounted for $10(33.3 \%)$ cases, comminuted fractures accounted for $8(26.7 \%)$ cases, oblique fractures accounted for 7 (23.3\%) cases, spiral fractures accounted for $5(16.7 \%)$ cases and there were no segmental fractures.

In the present series, average duration between trauma and surgery was 3.9 days. The average duration of surgery in our study was 59.9 minutes.

In our study, 21 (70\%) cases were immobilized (In above knee POP cast for femur and tibia fractures, "U" slab for humerus and Above elbow slab for forearm bone fractures) 
postoperatively for 6 weeks and such immobilization was for 9 weeks in rest of the $9(30 \%)$ of the cases. The period of immobilization was followed by active hip and knee, knee and ankle mobilization with non-weight bearing crutch walking for lower limb fractures, shoulder, elbow and wrist mobilization for upper limb fractures. The average duration of immobilization was 6.9 weeks.

The average duration of hospital stay in the present study is 11.6 days.

In our study union was achieved in $<12$ weeks in 24 $(80 \%)$ of the patients, $13-18$ weeks in $5(16.7 \%)$ and 20 wks. in $1(3.3 \%)$. Average time to union was 12.1 weeks.

In the present study, unsupported full weight bearing walking was started in $<12$ weeks for 19 (79\%) of the patients, between 13 and 18 weeks in $4(17 \%)$ and at 20 weeks in 1 (4\%) among the total of 24 lower limb fractures. The average time of full weight bearing was 11.5 weeks.

\begin{tabular}{|c|c|c|}
\hline Complications & No. of Patients (30) & Percentage \\
\hline Pain at nail insertion site & 3 & $10 \%$ \\
\hline Superficial infection & 1 & $3.3 \%$ \\
\hline Decreased ROM of joint & 2 (knee joint) & $6.6 \%$ \\
\hline Limb length discrepancy & $1(1 \mathrm{~cm})$ & $3.3 \%$ \\
\hline Angular deformity & $1\left(5^{0}\right)$ & $3.3 \%$ \\
\hline
\end{tabular}

\section{Assessment of Outcome}

In the present study, the final outcome was excellent in 22 $(73.33 \%)$ cases, satisfactory in $8(26.67 \%)$ cases and there are no poor outcome cases.

\section{TENS Outcome Score (Flynn et al)}

\begin{tabular}{|c|c|c|c|}
\hline & Excellent & Satisfactory & Poor \\
\hline $\begin{array}{c}\text { Limb length } \\
\text { inequality }\end{array}$ & $<1 \mathrm{~cm}$ & $1-2 \mathrm{~cm}$ & $>2 \mathrm{~cm}$ \\
\hline Malalignment & $<5^{0}$ & $5^{0}-10^{0}$ & $>10^{0}$ \\
\hline Unresolved pain & Absent & Absent & Present \\
\hline Complications & None & $\begin{array}{c}\text { Minor and } \\
\text { resolved }\end{array}$ & $\begin{array}{c}\text { Major and/or } \\
\text { lasting morbidity }\end{array}$ \\
\hline No .of cases (30) & 22 & 8 & 0 \\
\hline
\end{tabular}

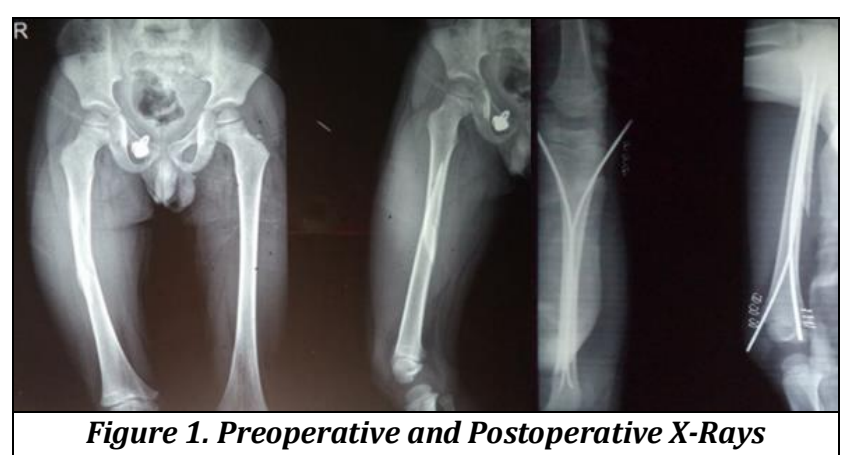

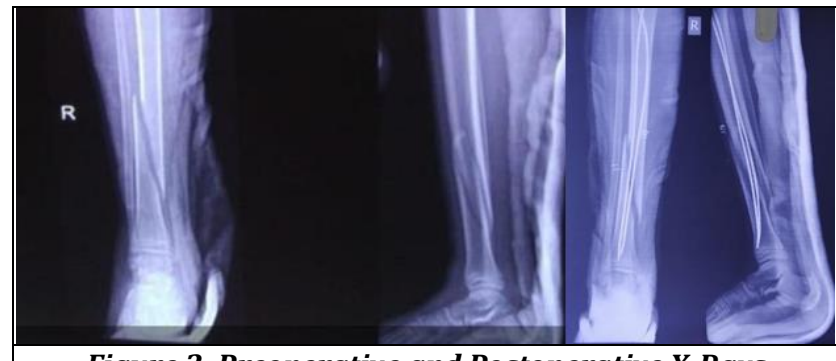

Figure 2. Preoperative and Postoperative X-Rays

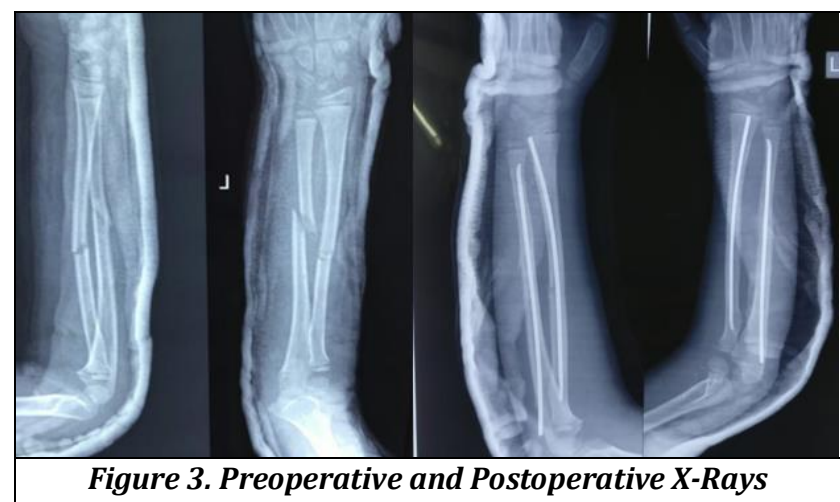

\section{DISCUSSION}

In our study, the average duration of immobilization was 6.9 weeks. It is shorter duration compared to conservative management. The advantage of the present study was early mobilization of the patients.

\begin{tabular}{|c|c|}
\hline Study & $\begin{array}{c}\text { Duration of Immobilization } \\
\text { (in Weeks) }\end{array}$ \\
\hline Present study & 6.9 \\
\hline $\begin{array}{c}\text { Gross R.H. et al. } \\
\text { (Immediate cast bracing) }\end{array}$ & 9.6 \\
\hline $\begin{array}{c}\text { John Ferguson } \\
\text { J } \\
\text { (Immediate hip Spica casting) }\end{array}$ & $10-12$ \\
\hline
\end{tabular}

The average duration of hospital stay in the present study is 11.6 days. Gross $\mathrm{RH}$, et al conducted a study on cast brace management of the femoral shaft fractures in children and young adults. The average length of hospitalization in their study was 18.7 days. $^{5}$

\begin{tabular}{|c|c|}
\hline Study & $\begin{array}{c}\text { Duration of Stay in } \\
\text { Hospital (in Days) }\end{array}$ \\
\hline Present study $^{\prime}$ & 11.6 \\
\hline Kalenderer O. et al ${ }^{7}$ (ender nail) & 12 \\
\hline Mann DC et al (elastic nail) $^{5}$ (cast bracing) & 11.4 \\
\hline Gross RH et al ${ }^{5}$ (cast & 18.7 \\
\hline
\end{tabular}

Compared to the above studies conducted on conservative methods and cast bracing, the average duration of hospital stay was less in our study i.e. 11.6 days.

In our study union was achieved in $<12$ weeks in 24 $(80 \%)$ of the patients, $13-18$ weeks in $5(16.7 \%)$ and 20 weeks in 1 (3.3\%). Average time to union was 12.1 weeks.

Aksoy $\mathrm{C}$, et al compared the results of compression plate fixation and flexible intramedullary nail insertion. Average time to union was 7.7 ( 4 to 10 ) months in the plating group and 4 (3 to 7) months for flexible intramedullary nailing. 


\begin{tabular}{|c|c|}
\hline Study & $\begin{array}{c}\text { Average Time for } \\
\text { Union (in Weeks) }\end{array}$ \\
\hline Present study $^{\text {Ond }}$ & 12.1 \\
\hline $\begin{array}{c}\text { Oh C.W. et al } \\
\text { intramedullary nail) }\end{array}$ & 10.5 \\
\hline $\begin{array}{c}\text { Aksoy C, et al }{ }^{10} \text { (Plating + flexible } \\
\text { intramedullary nail) }\end{array}$ & 16 \\
\hline
\end{tabular}

In our study, closed reduction of the fracture, leading to preservation of fracture hematoma, improved biomechanical stability and minimal soft tissue dissection led to rapid union of the fracture compared to compression plate fixation.

In the present study, unsupported full weight bearing walking was started in $<12$ weeks for $19(79 \%)$ of the patients, between 13 and 18 weeks in $4(17 \%)$ and at 20 weeks in $1(4 \%)$ among the total of 24 lower limb fractures. The average time of full weight bearing was 11.5 weeks.

Wudbhav N. Sankar et al. in their study allowed full weight bearing between $5.7-11.6$ weeks an average of 8.65 weeks. ${ }^{11}$

\begin{tabular}{|c|c|}
\hline Study & $\begin{array}{c}\text { Average Time of Start of Full } \\
\text { Weight Bearing (Weeks) }\end{array}$ \\
\hline Present Study & 11.5 \\
\hline Wudbhav N. Sankar ${ }^{11}$ & 8.65 \\
\hline
\end{tabular}

\begin{tabular}{|c|c|c|}
\hline Complications & $\begin{array}{c}\text { Present Study } \\
\text { (\%) } \\
\text { Titanium } \\
\text { Elastic Nail }\end{array}$ & $\begin{array}{c}\text { Previous Studies } \\
\text { (\%) } \\
\text { Titanium } \\
\text { Elastic Nail }\end{array}$ \\
\hline $\begin{array}{c}\text { Pain at The Site of Nail } \\
\text { Insertion }\end{array}$ & 10 & $\begin{array}{c}16.2 \\
\text { J. M. Flynn et al. }\end{array}$ \\
\hline Superficial Infection & 3.3 & $\begin{array}{c}1.7 \\
\text { J. M. Flynn et al. }\end{array}$ \\
\hline Decreased ROM & 6.6 & $\begin{array}{c}0.9 \\
\text { J. M. Flynn et al. }\end{array}$ \\
\hline Limb Lengthening & 0 & $\begin{array}{c}5(<1 \mathrm{~cm}) \\
\text { Ozturkman Y. et al. }\end{array}$ \\
\hline Limb Shortening & $3.3(<1 \mathrm{~cm})$ & $\begin{array}{c}2.5(<1 \mathrm{~cm})^{12} \\
\text { Ozturkman Y.et al }\end{array}$ \\
\hline Nail Back Out & 0 & $\begin{array}{c}2.6 \\
\text { Carey T.P. et } \text { al }^{13}\end{array}$ \\
\hline $\begin{array}{l}\text { Varus Valgus } \\
\text { Angulation }\end{array}$ & 3.3 & $\begin{array}{c}4.3 \\
\text { J. M. Flynn et al }\end{array}$ \\
\hline $\begin{array}{c}\text { Antero Posterior } \\
\text { Angulation }\end{array}$ & 0 & $\begin{array}{c}8 \% \text { Heinrich } \\
\text { SD et al }\end{array}$ \\
\hline Rotational Deformity & 0 & \begin{tabular}{|c|}
3.2 \\
Heinrich SD et al ${ }^{14}$
\end{tabular} \\
\hline
\end{tabular}

Pin tract infection is a major disadvantage of external fixation application. Bar-on E, et al reported 2 cases of deep pin tract infection in their patients treated with external fixation. ${ }^{15}$

John Ferguson et al noted more than $2 \mathrm{~cm}$ shortening in 4 children after Spica treatment of paediatric femoral shaft fracture. ${ }^{6}$

Herndon WA, et al compared the results of femoral shaft fractures by spica casting and intramedullary nailing in adolescents. They noticed varus angulation ranging from $7^{\circ}$ to $25^{\circ}$ in 4 patients treated with spica casting and no varus angulation in surgical group. ${ }^{16}$
Herndon WA, et al noticed anterior angulation ranging from $8^{\circ}$ to $35^{\circ}$ inpatients treated with traction and spica casting. 16

\section{Assessment of Outcome}

In the present study, the final outcome was excellent in 22 $(73.33 \%)$ cases, satisfactory in $8(26.67 \%)$ cases and there are no poor outcome cases. In D. Furlan and Z. Pogorelic study, the final outcome was excellent in $89 \%$ cases, satisfactory in $11 \%$ cases and there were no cases showing poor outcome. ${ }^{17}$

\begin{tabular}{|c|c|c|c|}
\hline Outcome (\%) & Excellent (\%) & Satisfactory (\%) & Poor (\%) \\
\hline Present Study & 73.33 & 26.67 & 0 \\
\hline $\begin{array}{c}\text { D. Furlan \& Z. } \\
\text { Pogorelic Study }\end{array}$ & 89 & 11 & 0 \\
\hline
\end{tabular}

\section{CONCLUSIONS}

Titanium Elastic Nailing System (TENS) technique is an ideal method for treatment of paediatric diaphyseal fractures of long bones. It is a simple, easy, rapid, reliable and effective method for management of paediatric long bone fractures in patients between 5 to 16 years of age, with shorter operative time, lesser blood loss, lesser radiation exposure and reasonable time to bone healing. It appreciably reduces the hospital stay and eliminates the need for prolonged bed rest. It gives elastic mobility promoting rapid union at fracture site and stability which is ideal for early mobilization. It is associated with lower complication rate, good outcome when compared with other methods of treatment. Because of early weight bearing, rapid healing and minimal disturbance of bone growth, TENS may be considered to be a physiological method of treatment and can be safely considered in the management of diaphyseal fractures of long bones in children and adolescents aged 5 to 16 years.

\section{REFERENCES}

[1] Metaizeau JP. Stable elastic nailing for fractures of the femur in children. J Bone Joint Surg $\mathrm{Br}$ 2004;86(7):954-7.

[2] El-Adl G, Mostafa MF, Khalil MA, et al. Titanium elastic nail fixation for paediatric femoral and tibial fractures. Acta Orthop Belg 2009;75(4):512-20.

[3] Flynn JM, Hresko T, Reynolds RA, et al. Titanium elastic nails for paediatric femur fractures - a multicenter study of early results with analysis of complications. J Pediatr Orthop 2001;21(1):4-8.

[4] Moroz LA, Launay F, Kocher MS, et al. Titanium elastic nailing of fractures of the femur in children: predictors of complications and poor outcome. J Bone Joint Surg Br 2006;88(10):1361-6.

[5] Gross RH, Davidson R, Sullivan JA, et al. Cast brace management of the femoral shaft fracture in children and young adults. J Pediatr Orthop 1983;3(5):572-82.

[6] Ferguson J, Nicol RO. Early spica treatment of paediatric femoral shaft fractures. J Pediatr Orthop 2000;20(2):189-92.

[7] Kalenderer 0, Agus H, Sanli C. Open reduction and intramedullary fixation through minimal incision with Ender nails in femoral fractures of children aged 6 to 
16 years. Acta Orthop Traumatol Turc 2002;36(4):303-9.

[8] Mann DC, Weddington J, Davenport K. Closed elastic nailing of femoral shaft fractures in adolescents. J Pediatr Orthop 1986;6(6):651-5.

[9] Oh CW, Park BC, Kim PT, et al. Retrograde flexible intramedullary nailing in children's femoral fractures. Int Orthop 2002;26(1):52-5.

[10] Aksoy C, Caolar O, Yazyoy M, et al. Pediatric femoral fractures: a comparison of compression plate fixation and flexible intramedullary nail fixation. J Bone \& Joint Surg (Br) 2003;85-B(Supp 3):263.

[11] Sankar WN, Jones KJ, Horn DB, et al. Titanium elastic nails for paediatric tibial shaft fractures. J Child Orthop 2007;1(5):281-6.

[12] Ozturkman Y, Dogrul C, Balioglu MB, et al. Intramedullary stabilization of paediatric diaphyseal femur fracture with elastic intramedullary nails. Acta Orthop Traumatol Turc 2002;36(3):220-7.
[13] Carey TP, Galpin RD. Flexible intramedullary nail fixation of paediatric femoral fractures. Clin Orthop Rel Res 1996;(332):110-8.

[14] Heinrich SD, Drvaric DM, Darr K, et al. The operative stabilization of paediatric diaphyseal femoral fractures: a prospective analysis. J Pediatr Orthop 1994;14(4):501-7.

[15] Bar-On E, Sagiv S, Porat S. External fixation or flexible intramedullary nailing for femoral shaft fractures in children. J Bone Joint Surg (Br) 1997;79(6):975-8.

[16] Herndon WA, Mahnken RF, Yngve DA, et al. Management of femoral shaft fractures in the adolescent. J Pediatr Orthop 1989;9(1):29-32.

[17] Furlan D, Pogorelic Z, Blocic M, et al. Elastic stable intramedullary nailing for paediatric long bone fractures: experience with 175 fractures. Scand J Surg 2011;100(3):208-15. 